\title{
HOW AN OPTOMETRIC COLLECTOR BECAME AN OPTOMETRIC ARCHIVIST
}

\author{
Michael J. Aitken, LOS.c. \\ Honorary Archivist \\ Kett Museum and Archives \\ Austraiian College of Optometry \\ michael.rosemary1@bigpond.com \\ doi: 10.14434/hindsight.v50i3.27566
}

\section{ABSTRACT}

This personal article looks at the long journey of an optometrist moving from the pursuit of collecting to the occupation of a volunteer optometry museum archivist. It is suggested that both collectors and archivists have a role to play in the development of museums.

\section{KEYWORDS}

Optometry archives; optometry books; optometry museums

A recent visit to the Ashmolean Museum in Oxford, England reminded me that this wonderful institution all started with the cabinet of curiosities which Elias Ashmole presented to the University of Oxford in 1677. In a similar manner the British Museum was founded on the bequest of the collection of Sir Hans Sloane when he died in 1753. And, of course, the Uffizi Gallery in Florence owes its genesis to the Medici family. In the same way, many museums and galleries all over the world have begun with the enthusiasm of private collectors.

I have always been a collector. As a small boy it was postage stamps and cereal food cards. Later it became old postcards and pre-decimal Australian coins. My student days at the Australian College of Optometry in Melbourne spanned the last four years of the 1950s. I recall in my final year buying a battered copy of J.S. Wells' On Long, Short and Weak Sight (London: 1862). It cost 4 shillings and 6 pence, about the same as a student café dinner at that time. I was excited by the book's antiquity. For sentimental reasons, I have kept my copy and, after nearly 60 years, it is considerably more antique than when I acquired it. Importantly this acquisition started me on antiquarian book collecting.

Soon afterward, I found in another Melbourne bookshop a 4th edition of William Mackenzie's A Practical Treatise of the Eye (London: 1854) in a lovely old calf binding. In over 1,000 pages, Mackenzie devoted just a few lines to the ophthalmoscope which had been recently invented by Hermann von Helmholtz. Astigmatism was barely given a mention and hypermetropia was not properly distinguished from presbyopia. Mackenzie did recognize hardness of the eye to be an essential characteristic of glaucoma. He also introduced the term asthenopia, and amusingly, advised that when all other treatments fail, sufferers should migrate to Australia.

When I graduated I spent my first months in an old established practice in the Victorian country city of Geelong. My elderly employer had serious loss of vision due to glaucoma, and he was not aware of the heavy dust and debris that had accumulated on the shelves of his storeroom. I felt like a real archeologist as I unearthed unsold stock that dated back to the early years of the twentieth century. I was kindly given small items such as pince-nez eyeglasses, lorgnettes, and curious sunglasses with side-shields. I was also presented with a very primitive ophthalmoscope and a simple 19th-century trial set.

In 1962, I made the long sea voyage to Europe and like many young Australians I wanted to explore some of the Old World. I had already become addicted to collecting early ophthalmic books and other historic optical items. I had made a couple of contacts and, when hitchhiking in the north of England, I called at an optometric practice in Yorkshire. Several early textbooks had been put aside for me and I recall being delighted to purchase, very reasonably, An Essay on Vision Briefly Explaining the Fabric of the Eye and the Nature of Vision by George Adams (2nd edition, London: 1792). I was impressed by the fact that one of our optometric forebears could publish such a book so early in our history. These few early books by opticians of the eighteenth century are all rare and very desirable. I like to think of such texts as being the incunabula or cradle books of optometry. I did not personally meet the Yorkshire optometrist on my visit but he must have been an exceedingly kind gentleman who wanted to encourage a young collector. He subsequently contacted 
me and sold me a fine copy of Isaac Newton's Opticks (the first Latin edition of 1706) for the sum of about just two English pub dinners!

During my travels over the rest of the 1960s and 1970s, I enjoyed buying antique spectacles and cases. I also bought ophthalmic textbooks by famous names like Donders and Jaeger. I was definitely hooked on rare book collecting but I found the ophthalmic material a lonely pursuit in Australia, and I eventually turned to Australiana. However, I have always felt that my enthusiasm was originally stimulated by my interest in early optometric history and for this reason I was very pleased to donate my small collection of ophthalmic books to the Australian College of Optometry when I retired.

In reviewing this collection, I realize that I personally rate most highly those books written by our early optometric predecessors. Newton, Helmholtz and Donders are, of course, among the great giants of optical history. However these men were inevitably scientists or physicians. Humble opticians were never highly educated, but at least a few managed to publish simple textbooks. These books were sometimes primarily intended to promote their own businesses but this is all part of our history. I have already mentioned George Adams, and in more recent years we have been able to acquire works by James Ayscough and Alexander Alexander. I also actively sought any early edition of Benjamin Martin's Essay on Visual Glasses.

In time I have realized that there are also a very few early books by American opticians, and even fewer by Australians. Our history is, of course, more recent than that of Europe and England. The equivalent items of significance belong to the late nineteenth century rather than the eighteenth century.

There were other influences on my ophthalmic collecting. On trips to Europe I have endeavored to visit optical museums in several countries. However it is the long established Museum of the British Optical Association which stands out above all. Thinking back to my student days, I recall that we were given eight lectures in the History of Optometry by Mr Cyril Kett. I don't know whether today's students receive any lectures on the history of our profession. Cyril Kett was a collector himself, and his significant collection of vintage and antique ophthalmic items eventually formed the nucleus of our College collection. This led to it being named The Cyril Kett Optometry Museum and Archive.

A number of other optometrists had an eye for optometric history. Charles Wright was a serious optometric historian and some of his collection of early books are now in the Kett collection. Another local optometrist, Charles Wantrup, clearly enjoyed picking up interesting small items and his collection was donated to othe Kett by his widow many years ago. Over subsequent years other thoughtful optometrists and their descendants have donated many and various historic artifacts.

My personal involvement with the Kett Museum goes back several decades. For a long time we made very slow progress. When my only archivist colleague died in the late 1980s, I nearly gave up on the project. However about 30 years ago, I was fortunate to be joined by a young and enthusiastic optometrist, Pamela Sutton. Like me, Pam was a keen collector of small antiquarian treasures, but additionally she took a much more academic interest in researching the artifacts. Our museum activity was further galvanized when our long-time head of the Australian College of Optometry, Professor Barry Cole, retired about the end of the twentieth century. He soon took on our museum and the history of optometry as a special retirement activity. Barry is decidedly not a collector, but he has brought his organizational skills and his wide knowledge of optometry to make great advances. We also have been recently joined by two more volunteer archivists, Colin Bates and Joseph Chakman, who both have very special skills and knowledge in defined areas to make our whole team a most effective unit.

We now digitally catalogue our collection and it is therefore available to the world via the internet. We have joined other museum associations and recently formed a "Friends Group."In 2019, we will have a new dedicated museum gallery to display a range of our best material.

This essay is taking a long ime to get to the point, which is that we all — collectors and museum professionals — all have a role to play. While I as a book collector would love to buy a copy of the first eye book published in Australia, my colleagues will variously see the value of the acquisition of a Culbertson prisoptometer or a trial set of haptic contact lenses or some historic documents on the early meetings of our professional associations. Collectors have a different mindset. They generally pay more attention to fine condition and they will often be more aware of rarity, and probably more alert to fakes and forgeries.

Slowly I am being persuaded that an optometric museum should not simply collect "old stuff." Optometry made immense progress through the second half of the twentieth century and, consequently, modern instrumentation, textbooks, lenses and eyewear all have a place in our history. As Professor Cole likes to point out, these objects will have the appeal of antiques in 100 years. It is up to archivists and curators to organize and preserve significant material for future historians and students.

Collectors, curators and archivists together have a role in illuminating history. I believe the history of optometry should be an important part of the culture of our profession. It is hoped that the Kett Museum and Archive will play a part as it has played a part in my personal journey in making the transformation from collector to archivist. 